\title{
Ou-Testamentiese perspektiewe op die definisie van die prediking
}

\author{
J P Oberbolzer \\ Universiteit van Pretoria
}

\begin{abstract}
Old Testament perspectives on the definition of preaching
\end{abstract}

The Old Testament antecedents to Christian preaching are considered briefly. It is found that the hymnic situation, that is the realisation of thanksgiving for salvation, in the Psalms comes closest to what is understood as preaching in the New Testament. The following amended definition of preaching is proposed for consideration: 'A pneumatological word event in which a person who is a believer himself, leads people, via a communication experience with a text of Scripture, to an encounter with and a life before the living God.

My kollega in die Praktiese Teologie, prof T F J Dreyer, het in Februarie 1989 die fakulteit geopen met 'n rede wat die beskeie titel gehad het van 'Poging tot 'n herdefinisie van die prediking binne die raamwerk van die Reformatoriese teologie' (Dreyer 1989:350-369). Dit was in meer as een opsig 'n belangwekkende rede en het die saak van die prediking op die agenda geplaas in die hermeneutiese gesprek wat reeds vir etlike jare in die Fakulteit gevoer word. Wat volg, is 'n bydrae tot hierdie gesprek, en wel vanuit die hoek van die Bybelwetenskap, meer bepaald die studie van die Ou Testament. Dit gaan oor die vraag na die Ou-Testamentiese antesedente van die Christelike en kerklike prediking.

Selfs dié vraag sal bevreemdend wees vir enigiemand wat met behulp van 'n konkordansie in die Ou Testament sou soek na die verskynsel prediking. Die woord

- Rede gehou tydens die opening van die adademiese jaar, Fakulteit Teologie (Afd A), Universiteit van Pretoria, 1 Feburarie 1990. 
self het, volgens Mynhardt, een keer voorgekom in die 1933-vertaling, naamlik in Jesaja 28:19, en ook dié een voorkoms het met die 1953 hersiening verval (Mynhardt 1963). Dit gaan om die weergawe van iłin 'wat gehoor word', wat binne die konteks te doen het met die aankondiging van straf in die vorm van 'n vloedgolf vyande wat die land sal oorstroom. Die 1933-weergawe lees: 'En dit sal net verskrikking wees om so 'n prediking te verneem'. Die 1953-hersiening het 'prediking' met 'openbaring' vervang. Die 1983-vertaling se weergawe is: 'Dan sal dit louter verskrikking wees om die boodskap uit te lê wat ontvang is'. Die 1983vertaling gebruik die woord prediking wel ook 'n enkele keer, naamlik in Jesaja 8:16: 'Bly eers stil oor my prediking, laat my volgelinge vir hulleself hou wat ek hulle geleer het' (Cinamon 1984). Hier is die 1933-1953 weergawe: 'Bind die getuienis toe, verseël die wet in in die hart van my leerlinge'. Die Hebreeuse woord wat in 1933 met 'getuienis' en in 1983 met 'prediking' weergegee is, is word'. Met hierdie twee voorkomste van die woord 'prediking' is die saak dan afgedaan wat betref die Afrikaanse Bybel, behalwe dat die woord 'preek' ook in Jona 1:2 en 3:4 in die 1933/1953-Afrikaanse vertaling voorkom. Ook die Good News Bible en die New International Version het nie geleentheid gevind om die woorde 'preach' en 'preaching' in die Ou Testament te gebruik nie.

In die kort artikel oor prediking in die Interpreter's Dictionary of the Bible wys Menoud aan dat daar ' $n$ rede voor is dat ons nie in die Ou Testament van prediking lees nie. Hy sê die Nuwe-Testamentiese skrywers maak 'n duidelike onderskeid tussen prediking en leer. Prediking is die aankondiging van die evangelie vir mense wat dit nog nie gehoor het nie. Leer is onderrig of vermaning oor verskillende aspekte van die Christelike lewe en denke, gerig tot 'n gemeenskap wat reeds in die geloof gevestig is. Hierdie verskil tussen prediking en leer verklaar waarom die OuTestamentiese skrywers nouliks die term 'preek' gebruik om die funksie van die profete te beskryf. Hulle funksie was om die uitverkore volk te vermaan om getrou aan hulle God te bly. Dit kan goed vergelyk word met die taak van die Christelike prediker van vandag. Hierdie profete het nie nuus gebring nie; hulle het gevra vir 'n beter en strenger gehoorsaamheid aan die gegewe wet. Net in twee gevalle het die terme 'prediking' en 'preek' in die profete hulle vroeg Christelike betekenis. Eerstens in die boek Jona waar die profeet die boodskap van God aan nie-Jode moet verkondig en tweedens in Jesaja waar die blye boodskap van die eskatologiese redding aangekondig word (Menoud 1962). Menoud definieer die Christelike prediking as die "openbare proklamering van die "blye boodskap" - dit is die evangelie aan die nie-Christelike wêreld'.

Mounce (1962) aanvaar 'n soortgelyke definisie wat hy oorneem van Dodd. Hy verklaar egter: 
Hoewel ons prediking gedefinieer het binne eng grense om so die essensieel Nuwe-Testamentiese betekenis daarvan te beklemtoon, wil dit nie sê dat dit sonder presedent in die Ou Testament is nie. Die Hebreeuse profete was beslis voorlopers van die apostoliese herout toe hulle die boodskap van God onder goddelike ingewing geproklameer het.

Mounce wys ook daarop dat prediking en leer wel te onderskei is, maar dat hulle op dieselfde feite berus. Die kípuy $\mu \alpha$ proklameer wat God gedoen het, die $\delta \dot{\delta} \alpha \times \dot{n}$ leer die implikasies daarvan vir die Christelike lewenswyse.

Aandag word aan nog een naslaanwerk geskenk, naamlik die baie nuttige Handbuch theologischer Grundbegriffe waarvan die hersiene eerste druk in 1970 verskyn het, en waar Hermann onder die hoof 'Verkündigung' die Bybelse gedeelte behandel. Hy stel die volgende:

Die basis van die Bybelse verkondiging - as gebeure gesien - is die bewussyn van die verkondiger dat hy in die Naam van God praat. Die sendingbewussyn wat by die Ou-Testamentiese profete tot stand gekom het (vgl Jer 1:9 - 'Ek het nou my woorde in jou mond gelê'), geld eerstens vir Jesus self (Luk 4:18vv), en van Hom uit ook vir sy sendelinge (ámóotodol).

Hermann wys dan op die samehang tussen geloof en verkondiging, en tussen verkondiging en sending wat in Romeine 10:14-18 uitgespreek word, en haal Romeine 10:17 aan: 'Die geloof kom dus deur die prediking wat ons hoor, en die prediking wat ons hoor, is die verkondiging van Christus' ( $\rho$ గi $\mu \alpha$ xplotov). In aansluiting by Michel stel hy dan: Hierdie woord van Christus is dus dié werklikheid van waaruit die hele proses van die verkondiging uitgaan. In die verkondiging verneem die mens die sprekende Kúplos, en spesifiek die verhoogde Kúplos. Soos Christus, werk ook die menslike verkondiging as gevolmagtigde werktuig van God se heilsverkondiging. Samevatting van sy heilbrengende teenwoordigheid is Christus in wie se plek die apostel God se oproep tot versoening deur die tyd dra. Wanneer die apostel in 2 Korintiërs 5:20 sê: 'Ons smeek julle namens Christus: Aanvaar die versoening met God wat Hy bewerk het', kom daarmee die sentrale tema van die Nuwe-Testamentiese verkondiging te voorskyn, naamlik God wat tot versoening bereid is, wat Hom in Christus openbaar. Hermann wys dan verder op die verskil in benadering tussen verkondiging in die Joodse wêreld waar al die klem daarop lê dat die God van die vadere Hom nou finaal in Christus bekendgemaak het en in Hom 
die messiaanse heilstyd aangebreek het, en die heidenwêreld waar die verkondiging van die een God teenoor die vele van die heidendom voorafgaan aan die Christologiese kerugma.

Ek meen dat dié drie gesaghebbende artikels waarna ek verwys het, voldoende aantoon dat prediking 'n essensieel Nuwe-Testamentiese saak is. Dit kom aan die orde ná die inkarnasie en dit het tot inhoud Jesus Christus, sy werk en sy betekenis. Met ons vraag na die Ou-Testamentiese agtergrond van die Christelike prediking het ons dus byvoorbaat afgesien van die moontlikheid van kontinuïteit vanaf die $\mathrm{Ou}$ Testament na die Nuwe Testament toe, minstens wat betref die Gattung prediking en sy Sitz im leben.

Dit is wel waar dat ons via die beproefde metode van woordondersoek gebring word by Ou-Testamentiese tekste waar ons iets aantref wat baie naby staan aan wat ons prediking sou noem, naamlik dié woordgebeure waarin mense aan ander mense iets oor God en sy werk kommunikeer. Dit is veral die áy $y \dot{\varepsilon} \lambda \lambda \omega$-woordgroep wat ons via die Septuagint bring by die oorvloedige voorkoms van die gedagte van kommunikasie van die kennis van God en wat Hy gedoen het. In hierdie opsig lewer veral die Psalmboek verrassende gegewens. Die genoemde woordgroep bring ons

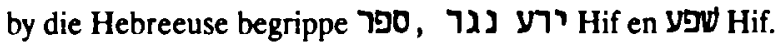

Oor ספר skryf Conrad (TWAT V, 91-95):

In besondere mate egter, en wel hoofsaaklik in die Psalms, is die magsvolle heilsdade van Jahwe die inhoud van die menslike vertelling. Hierin gaan dit nou nie om 'n eenvoudige verder-vertelling in die sin van 'n ervaringsberig (soos in Eks 18:8) nie. Veeleer moet deur die vertelling van heilsdade wat beleef is en wat deur oorlewering bekend is, die heilvolle werking van Jahwe algemeen teenwoordig gemaak en verkondig word...Hierdie heilsdade word vertel omdat hulle van blywende betekenis is, naamlik as tekens daarvan dat Jahwe na dié wat aan Hom behoort en op Hom vertrou, toegekeer is....Daarom moet hulle van geslag tot geslag verder vertel om hierdie toewending steeds opnuut te betuig....So 'n getuienis geld egter nie net Israel nie. Jahwe is Heer van die hele wêreld. Sy handeling aan Israel en die enkeling is van universele betekenis en oral werksaam. Sy heilsdade moet daarom in die hele wêreld verkondig word.

(Ps 96:3 - 'Vertel die nasies van sy mag, al die volke van sy magtige dade') 
Oor נגר skryf Garcia-Lopez (TWAT V:198):

In die Psalms, veral in die himnes, word 72 serhaaldelik gebruik om die proklamasie van die heilsdade van Jahwe, die lof aan die God wat Hom aan mense manifesteer, uit te druk....In hierdie tekste beteken נגר sowel die lof van God, die verkondiging van sy geregtigheid en sy werke, as die openbaring of manifestasie van God self.

ירע word in die Psalms gebruik vir die verkondiging van die trou van God aan volgende geslagte (89:2) en die bekendmaking aan die nasies van wat Hy gedoen het (105:1). עפש word gebruik vir die verkondiging van die lof van die Here (Ps 66:8; 106:2).

Soos Garcia-Lopez aangetoon het ten opsigte van נגר, bevind ons ons in al hierdie gevalle min of meer in die himniese situasie of in die realisering van dankbaarheid vir die ontvange verlossing. Ook בשר Pi, wat in die Septuagint

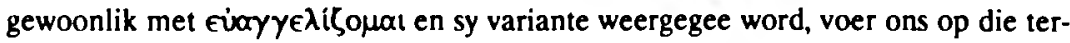
rein van die dankbare getuienis oor die redding wat ervaar is (Ps 40:10; 96:2). Hierdie woordgroep bring egter in Jesaja 40:9; 41:27; 52:7 iets besonders na vore, naamlik die aankondiging van die voor die deur staande redding, terwyl in Nehemia 1:15 (2:1) dit slaan op die goeie nuus dat die vyand verslaan is. Die eskatologiese heil is in Jesaja 61:1 die voorwerp van בשר: '...die Here het my gesalf om 'n blye boodskap te bring aan die mense in nood'. In dieselfde vers gebruik die Septuagint ook die woord knpúorw vir die aankondiging van vrylating vir die gevangenes.

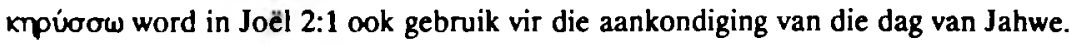
Dit is welbekend dat Jesaja 61:1-2 'n geliefde invalshoek is vir die interpretasie van die figuur van Jesus as die verwagte eskatologiese heilsgestalte (Luk 4:16-19; Matt 11:5; Luk 7:22).

Dié gedagte, van die finale en volledige selfbekendmaking van die God van Israel in die figuur van Jesus Christus, impliseer meteen die belang van die hele $\mathrm{Ou}$ Testament vir die prediking van die Christelike Kerk. Wie die Jesus is wat verkondig moet word, kan alleen begryp word teen die volle agtergrond van die geskiedenis van God met die mense van die begin af. 'In Hom is die volle wese van God beliggaam' (Kol 2:9; vgl 1:19).

Wie Jesus Christus is as die Logos en as die versoeningswoord van God wat die wêreld opnuut grondves, dit weet die gemeente van Jesus Christus eers wanneer hy met die Ou Testament oor die oorsprong en bestemming van die skepping nagedink het. Eers wanneer dit gebeur 
het, kan Jesus werklik aan die wèreld as versoener en heilbrengende openbaringswoord verkondig word.

(Stuhlmacher 1979:244vv)

$\mathrm{Na}$ hierdie bevindings kom die vraag seker aan die orde of dit korrek is om die antesedente van die Nuwe-Testamentiese prediking by die profete van die $\mathrm{Ou}$ Testament te soek. Ons ondersoek het ons immers telkens gelei na ander situasies, veral dan dié wat in die Psalms betuig word. Die roeping van die profeet, sy opdrag en die uitvoering daarvan het met die verkondiger alleen die patroon in gemeen van die dienaar van God wat sy funksie uitoefen in die verhouding tussen God en mense. Dit is die moeite werd om in die verband kennis te neem van Füglister se uitsprake (Handbuch theologischer Grundbegriffe, Band 3, p367vv). Hy stel ten aanvang:

Die Ou-Testamentiese profetegestaltes het die historiese ontstaansproses van die Israelities-Christelike openbaringsgodsdiens beslissend beïnvloed; derhalwe neem die Bybelse profetegeskrifte 'n sentrale plek in in die kanon en in die vroeg-Christelike verkondiging en vroomheid (vgl bv 2 Pet 1:19vv en die Niceens-Konstantinopolitaanse geloofbelydenis ('wat gespreek het deur die heilige profete')....'Profeet' kom in die oerkerugma voor as ou Christologiese titel (Hand $3: 22 ; 7: 37$ ), die gelowiges word deur die uitgieting van die Gees op Pinkster as nuwe Israel van die messiaanse heilstyd grondig profeties toegerus (Hand 2:17v), en die kerk word nie net op die apostelamp nie maar net soseer op die profetedom gegrond (Ef 2:20) as twee wedersyds bepalende en aanvullende konstitutiewe funksies....As een wat gekies en gestuur is, is die Ou-Testamentiese profeet opdragdraer en orgaan van Jahwe. Saam met die ander Jahwe-organe - die koning en priester - het hy in diens van die Verbondsgod 'n baie besondere taak om te vervul in en aan die verbondsvolk....Soos in die Ou-Testamentiese Israel naas die profeet die koning en die priester staan, so werk in die kerk naas die profeet en saam met hom die ander gevolmagtigdes, die apostel in die eerste plek sowel as die leraar en die oudstes.

Dit is wel waar dat die gestalte van Paulus sterk profetiese trekke vertoon, byvoorbeeld wat betref sy roeping, openbaringsbelewenis en martyrium, maar hierdie 
trekke is nie sonder meer eie aan die gestalte van die prediker nie, minstens dan nie op dieselfde wyse nie. Bowendien moet ons nie uit die oog verloor nie dat die apostelamp 'n unieke amp was wat binne 'n bepaalde tyd sy plek gehad het. Soos in die Ou Testament die verkondiging van die groot dade van God en die getuienis oor sy heilswerk voortkom uit die reddingsgebeure in die lewe van volk en individu, so geskied in die Nuwe Testament die verkondiging vanuit die persoon en werk van Christus. Die profetewoord kom voort uit direkte openbaring, die apostelwoord uit die persoonlike ontmoeting met die opgestane Heer, die prediking uit die getuienis van profete en apostels.

Ook langs hierdie weg kom ons uiteindelik by die onontwykbare vraag na die verstaan en interpretasie van hierdie getuienis. Die vraag na Jesus as inhoud van die verkondiging is dan tegelyk die vraag na die weg van God met die mense van die begin af, 'n weg waarvan ons net in die Heilige Skrif kan kennis neem. Die paradigma vir hierdie kennisname lề vir die Christelike kerk nèrens anders nie as in die Persoon van Jesus Christus. Die talle wyses waarop in die Nuwe Testament aangedui word dat die Ou Testament as getuienis op Christus heen gelees moet word, kan nie deur die kerk genegeer word nie. Verantwoordelike teologie stel die eis dat oor die volle wydte van die teologiese ensiklopedie gearbei sal word met die beste beskikbare wetenskaplike apparaat, maar dat die pastorale bewoënheid daarby nooit sal ontbreek nie. Wat ons betref, geld hierdie bewoënheid die mens van nou in sy situasie van nou.

Hier, in die betrokkenheid op die situasie van nou, kom die opdrag van die dienaar van die Goddelike woord in sy volle omvang na vore:

...die Woord van die Here soos dit in die Heilige Skrif geopenbaar is, grondig en opreg...verkondig. Hulle moet dit in die algemeen en in die besonder tot redding van die hoorders doen, deur hulle te onderrig, te vermaan, te vertroos en te bestraf, soos dit in elke geval nodig is. Hulle moet die bekering tot God en die versoening met Hom deur die geloof in Jesus Christus verkondig, en met die Heilige Skrif alle dwalinge en ketterye wat in stryd met die suiwer leer is, weerlè.

(Diensboek 1983:83)

Die redding van die hoorders, bekering tot God en versoening met Hom is hiervolgens die doel van die prediking. Dit roep meteen die Ou Testament in sy geheel op die toneel: die leer oor die wil van God, die kultus, die profetewoord, die 
klag, vertroue en dank van enkeling en volk, die worsteling om lewenskunde, die verwagting van die eskatologiese heil ten spyte van mense. Redding, bekering en versoening is ryk, gevarieerde, gelade begrippe wat slegs Bybels-teologies ontgin kan word. Die wyse van verkondiging, nl. onderrig, vermaning, vertroosting en bestraffing, voer ons wat die Ou Testament betref na vorm en inhoud van die literatuur, en herinner ons daaraan dat soos die geskrifte van die Nuwe Testament neerslag is van die prediking van die aspostoliese tydvak en die eerste jare daarna, ook die Ou-Testamentiese geskrifte gebore is uit kommunikatiewe handelinge wat die Godsvolk gekonfronteer het met die teenwoordigheid en die wil van God. Leer, parenese, paraklese en teregwysing het hierdie teenwoordigheid betuig en hierdie wil in sy volle gesag afgekondig.

Ons het nou beweeg vanaf die eng definisie van die prediking as die openbare proklamering van die Blye Boodskap aan die nie-Christelike wêreld tot by die omvattende spreektaak van die dienaar van die Woord soos die formulier dit omskrywe. Dit was steeds duidelik dat hierdie spreekhandeling nie vanuit die Nuwe Testament alleen geformuleer of omskryf kon word nie, maar uit die hele Skrif. Ter afsluiting kan ons nou aandag gee aan die definisie van Dreyer (1989:365): 'Prediking is 'n pneumatologiese woordgebeure waarin 'n geroepe dienaar van die Woord via 'n kommunikasie-ervaring met 'n Skrifteks die gemeente in sy konkrete situasie begelei tot 'n ontmoeting met die lewende God.' Dat Dreyer as kerklike teoloog die ampsgebondenheid van die prediking in sy definisie inbou en ook nog die adres van die woordgebeure tot die gemeente beperk, is begryplik. Vanuit die Bybelse perspektief sou 'n mens egter in albei gevalle vrae moet stel. Die prediking wat die dimensie van proklamasie aan die nie-Christelike wêreld ontbeer, het afskeid geneem van 'n belangrike deel van die identiteit van die kerk, en die onderskeie elemente wat die formulier beklemtoon, naamlik leer, vermañing, vertroosting en bestraffing word in die Skrif nie vir ampsdraers gereserveer nie. Ook die aangegewe doel van die prediking, naamlik begeleiding tot die ontmoeting met die lewende God, wek vrae. Die doel pas uitstekend by die verkondiging aan die nie-Christelike wêreld, maar in die kerk is prediking ook begeleiding ná die ontmoeting. Ter wille van die debat lê ek dan die volgende geamendeerde definisie van die prediking voor:

'n Pneumatologiese woordgebeure waarin 'n persoon wat self 'n gelowige is, via 'n kommunikasie-ervaring met 'n Skrifteks, mense begelei tot 'n ontmoeting met en 'n lewe voor die lewende God. 


\section{Literatuurverwysings}

Cinamon, D V 1984. Die Nuwe Vertaling Bybelkonkordansie. Ravenmoor: Sceptre.

Dreyer, T F J 1989. 'n Poging tot 'n herdefinisie van die prediking binne die raamwerk van die Reformatoriese teologie. HTS 45, 350-369.

Handbuch theologischer Grundbegriffe 1974. 2de druk. Deutsche Taschenbuch Verlag.

Menoud, P H 1962. s v Preaching. IDB.

Mounce, R H 1962. s v Preaching. New Bible Dictionary.

Mijnhardt, C F 1963. Afrikaanse Bybelkonkordansie. 4de druk. Pretoria: Van Schaik.

Nederduitsch Hervormde Kerk van Afrika 1983. Diensboek Pretoria: Kital.

Stuhlmacher, P 1979. Vom Verstehen des Neuen Testaments. Göttingen: Vandenhoeck. 